Research Article

\title{
The lipidome, genotoxicity, hematotoxicity and antioxidant properties of andiroba oil from the Brazilian Amazon
}

Susana Suely Rodrigues Milhomem-Paixão ${ }^{1}$, Maria Luiza Fascineli ${ }^{2}$, Mariana Matos Roll ${ }^{3}$, João Paulo Figueiró Longo ${ }^{2}$, Ricardo Bentes Azevedo ${ }^{2}$, Julio Cesar Pieczarka ${ }^{1}$, Hugo Leonardo Crisóstomo Salgado ${ }^{4}$ Alberdan Silva Santos ${ }^{4}$ and Cesar Koppe Grisolia ${ }^{3}$

${ }^{1}$ Laboratório de Citogenética, Instituto de Ciências Biológicas, Universidade Federal do Pará (UFPA), Belém, PA, Brazil.

${ }^{2}$ Laboratório de Nanobiotecnologia, Departamento de Genética e Morfologia, Instituto de Ciências Biológicas, Universidade de Brasília (UnB), Brasília, DF, Brazil.

${ }^{3}$ Laboratório de Genética Toxicológica, Departamento de Genética e Morfologia, Instituto de Ciências Biológicas, Universidade de Brasília (UnB), Brasília, DF, Brazil.

${ }^{4}$ Laboratórios de Investigação Sistemática em Biotecnologia e Biodiversidade Molecular (LabISisBio), Instituto de Ciências Exatas e Naturais, Universidade Federal do Pará (UFPA), Belém, PA, Brazil.

\begin{abstract}
Andirobeira is an Amazonian tree, the seeds of which produce a commercially valuable oil that is used in folk medicine and in the cosmetic industry. Andiroba oil contains components with anti-inflammatory, cicatrizing and insect-repellant actions. However, virtually nothing is known of the safety of this oil for humans. The aim of this work was therefore to investigate the hematotoxicity, genotoxicity and mutagenicity of andiroba oil using the comet and micronucleus assays, and to assess its antioxidant properties and lipidome as a means of addressing safety issues. For the experiments, andiroba oil was administered by gavage for 14 consecutive days in nulliparous female Swiss mice randomly distributed in four groups: negative control and three doses of oil (500, 1000 and $2000 \mathrm{mg} / \mathrm{kg} /$ day). These doses were chosen based on recommendations of the OECD guideline no. 474 (1997). GC/MS was used to investigate the free fatty acid, cholesterol and triterpene content of andiroba oil in a lipidomic analysis. No clinical or behavioral alterations were observed throughout the period of treatment, and exposure to andiroba oil at the doses and conditions used here did not result in hematotoxic, genotoxic or mutagenic effects. Tests in vitro showed that oil sample 3 from southwestern of Brazilian Amazon had a high antioxidant capacity that may protect biological systems from oxidative stress, although this activity remains to be demonstrated in vivo.
\end{abstract}

Keywords: acute toxicity, antioxidant activity, Carapa guianensis, genotoxicity, lipidomics.

Received: April 13, 2015; Accepted: August 22, 2015.

\section{Introduction}

Andiroba oil is extracted from the seeds of the andiroba tree, represented by two species, Carapa guianensis and Carapa procera, of the family Meliaceae that occurs in the Amazon (Fisch et al., 1995). This oil has various uses in folk medicine, such as a cicatrizing and anti-inflammatory agent and as an insect repellent (Bauch and Dunisch, 2000; Ferraz et al., 2002; Shanley et al., 2005); in recent years, andiroba oil has also been used intensively in the cosmetic industry (Ferreira et al., 2010).

Send correspondence to C. K. Grisolia. Laboratório de Genética Toxicológica, Departamento de Genética e Morfologia, Instituto de Ciências Biológicas, Universidade de Brasília (UnB), Brasília, 70910-900, DF, Brazil. E-mail: grisolia@unb.br.
Previous studies have reported acaricidal (Farias et al., 2007, 2009), larvicidal (Silva et al., 2004), insect repellent (Miot et al., 2004, 2011) and antiplasmodial (Miranda Júnior CRN, 2010, MSc dissertation, Universidade Federal do Pará, Belém, PA, Brazil) activities for andiroba oil. However, a general lack of knowledge regarding the toxicity and/or proof of pharmacological activities of natural products employed as medicines and their indiscriminate use may put Amazon populations at risk of adverse reactions (Frescura VDA, 2012, MSc dissertation, Universidade Federal de Santa Maria, Santa Maria, RS, Brazil).

Andiroba oil is rich in essential fatty acids, including oleic, palmitic, stearic and linoleic acids (Martinborough, 2002; Rain-Tree, 2014). Linoleic acid reduces cholesterol levels and blood pressure and is beneficial in the prevention of cancer. Andiroba oil also contains meliacines, a group of 
substances that confer a bitter taste to the oil and have antimalarial and antiparasitic activities; there are also limonoids with anti-inflammatory, insect repellent and anti-tumoral properties (Martinborough, 2002; Rain-Tree, 2014).

Stearic, palmitic, oleic and linoleic fatty acids can cause apoptosis in different cell lines in vitro, depending on the concentration tested (Mu et al., 2001; Lu et al., 2003; Cury-Boaventura et al., 2004). There has been much discussion about the possible mechanisms involved in the induction of apoptosis by these acids and the physiological effects that they produce (Curi et al., 2002). One of the best characterized mechanisms in apoptosis involves damage to cellular DNA that may occur via various routes (Batista LFZ, 2008, PhD thesis, Universidade de São Paulo, São Paulo, SP, Brazil). This damage can be eliminated by the endogenous DNA repair system of cells, but if the damage persists it may induce genotoxicity, mutagenesis or even apoptosis (Wong et al., 2005; Asare et al., 2011; Batista LFZ, 2008, PhD thesis, Universidade de São Paulo, São Paulo, SP, Brazil).

Knowledge about the genotoxic potential of natural compounds and semi-synthetic and synthetic chemicals is essential for regulatory agencies so that they can establish the risk to humans (Ribeiro et al., 2003). To date, few studies have examined the toxicity of andiroba oil and there are no reports on the possible genotoxic or mutagenic effects of this oil. The aim of this work was therefore to investigate the possible toxicological, mutagenic and genotoxic effects of andiroba oil in Swiss mice and to examine the antioxidant properties of this oil in vitro. The data obtained contribute to our understanding of the safety of this oil and its saponified fraction.

\section{Material and Methods}

\section{Plant material}

Seeds from andiroba trees were collected from 21 sites in the state of Pará in the Brazilian Amazon under license no. MMA/ICMBIO/SISBIO-33336-1 issued by the Brazilian Environmental Agency. The sample identifications, mesoregions, municipalities, geographical coordinates and collection periods for these seeds are described in Table 1. The exsicates were deposited in the herbarium of the Brazilian Agricultural Research Company

Table 1 - Samples, localities and periods of collection of andiroba seeds and the concentration of oil causing a $50 \%$ reduction in the $\mathrm{DPPH}$ radical (EC $\mathrm{EC}_{50}$ ).

\begin{tabular}{|c|c|c|c|c|c|}
\hline Samples & Mesoregion & Municipality & Geographical coordinates & $\begin{array}{l}\text { Collection } \\
\text { period }\end{array}$ & $\mathrm{EC}_{50}(\mu \mathrm{L} / \mathrm{mL})$ \\
\hline SE1 & Southeast & Nova Ipixuna & $\mathrm{S} 04^{\circ} 48^{\prime} 30.1^{\prime \prime} \mathrm{W} 049^{\circ} 21^{\prime} 42.8^{\prime \prime}$ & $16-20 / 4 / 12$ & 86.62 \\
\hline SE2 & Jacundá & 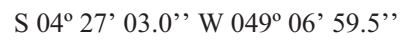 & $16-20 / 4 / 12$ & 151.0 & \\
\hline SE3 & São Miguel do Guamá & $\mathrm{S} 01^{\circ} 35^{\prime} 28.5^{\prime \prime} \mathrm{W} 047^{\circ} 34^{\prime} 39.5^{\prime \prime}$ & $3-7 / 5 / 2012$ & 126.7 & \\
\hline NE1 & Northeast & Abaetetuba & $\mathrm{S} 01^{\circ} 43^{\prime} 04^{\prime \prime} \mathrm{W} 048^{\circ} 52^{\prime} 58^{\prime \prime}$ & $3-7 / 5 / 2012$ & 2305 \\
\hline NE2 & Acará & $\mathrm{S} 01^{\circ} 58^{\prime} 25.9^{\prime \prime} \mathrm{W} 048^{\circ} 18^{\prime} 49.5^{\prime \prime}$ & $3-7 / 5 / 2012$ & 302.0 & \\
\hline NE3 & Cametá & $\mathrm{S} 02^{\circ} 14^{\prime} 40.0^{\prime \prime} \mathrm{W} 049^{\circ} 29^{\prime} 45.0^{\prime \prime}$ & $3-7 / 5 / 2012$ & 204.3 & \\
\hline LAM1 & Lower Amazon & Santarém & $\mathrm{S} 02^{\circ} 24^{\prime} 52^{\prime \prime} \mathrm{W} 054^{\circ} 42^{\prime} 36.0^{\prime \prime}$ & $25-29 / 3 / 2012$ & 43.56 \\
\hline LAM2 & Oriximiná & 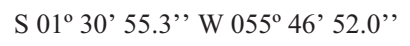 & $25-29 / 3 / 2012$ & 150.7 & \\
\hline LAM3 & Óbidos & $\mathrm{S} 01^{\circ} 39^{\prime} 21.5^{\prime \prime}$ W $055^{\circ} 37^{\prime} 15.9^{\prime \prime}$ & $25-29 / 3 / 2012$ & 45.20 & \\
\hline MAR1 & Marajó & Curralinho & $\mathrm{S} 01^{\circ} 45^{\prime} 59.1^{\prime \prime} \mathrm{W} 049^{\circ} 49^{\prime} 45.2^{\prime \prime}$ & $\begin{array}{c}12 / 4 ; 23 / 5 \text { and } \\
24 / 7 / 2012\end{array}$ & 468.9 \\
\hline MAR2 & Salvaterra & $\mathrm{S} 00^{\circ} 48^{\prime} 02.0^{\prime \prime} \mathrm{W} 048^{\circ} 32^{\prime} 01.0^{\prime \prime}$ & $12 / 4 ; 23 / 5$ and $24 / 7 / 2012$ & 90.23 & \\
\hline MAR3 & Breves & $\mathrm{S} 01^{\circ} 38^{\prime} 17.9^{\prime \prime} \mathrm{W} 050^{\circ} 27^{\prime} 99.5^{\prime \prime}$ & $12 / 4 ; 23 / 5$ and $24 / 7 / 2012$ & 1894 & \\
\hline MTR1 & Metropolitan & Santa Isabel do Pará & $\mathrm{S} 01^{\circ} 21^{\prime} 12.4^{\prime \prime} \mathrm{W} 048^{\circ} 08^{\prime} 37.3^{\prime \prime}$ & $29 / 3-1 / 4 / 2012$ & 326.3 \\
\hline MTR2 & Castanhal & $\mathrm{S} 01^{\circ} 17^{\prime} 49.5^{\prime \prime} \mathrm{W} 047^{\circ} 55^{\prime} 19.7^{\prime \prime}$ & $29 / 3-1 / 4 / 2012$ & 559.3 & \\
\hline MTR3 & Bujarú & $\mathrm{S} 01^{\circ} 35^{\prime} 46.3^{\prime \prime} \mathrm{W} 047^{\circ} 57^{\prime} 32.9^{\prime \prime}$ & $29 / 3-1 / 4 / 2012$ & 252.6 & \\
\hline SW1 & Southwest & Porto de Moz & $\mathrm{S} 01^{\circ} 45^{\prime} 00^{\prime \prime} \mathrm{W} 052^{\circ} 14^{\prime} 15.0^{\prime \prime}$ & $25-29 / 3 / 2012$ & 425.4 \\
\hline SW2 & Medicilândia & 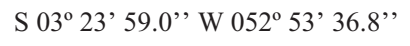 & $12 / 3-24 / 4 / 2012$ & 1181 & \\
\hline SW3 & Uruará & $\mathrm{S} 03^{\circ} 58^{\prime} 31.7^{\prime \prime} \mathrm{W} 053^{\circ} 37^{\prime} 32.1^{\prime \prime}$ & $12 / 3-24 / 4 / 2012$ & 59.95 & \\
\hline SW4 & Itaituba & $\mathrm{S} 04^{\circ} 16^{\prime} 34.0^{\prime \prime}$ W $055^{\circ} 59^{\prime} 01.0^{\prime \prime}$ & $29 / 3-5 / 4 / 2012$ & 150.0 & \\
\hline SW5 & Jacareacanga & $\mathrm{S} 06^{\circ} 13^{\prime} 20.0^{\prime \prime} \mathrm{W} 057^{\circ} 45^{\prime} 10.0^{\prime \prime}$ & $29 / 3-5 / 4 / 2012$ & 100.4 & \\
\hline SW6 & Aveiro & $\mathrm{S} 03^{\circ} 50^{\prime} 30.0^{\prime \prime} \mathrm{W} 055^{\circ} 28^{\prime} 32.7^{\prime \prime}$ & $29 / 3-5 / 4 / 2012$ & 106.7 & \\
\hline IANA* & & & & & 8913 \\
\hline AMAZON* & & & & & 204.8 \\
\hline
\end{tabular}

$\mathrm{S}$ - South, W - West. $\mathrm{EC}_{50}$ : minimum concentration required to reduce $50 \%$ of DPPH. *Commercial samples: Amazon Ervas and Iana ${ }^{\circledR}$ D'amazônia. 
(EMBRAPA) under accession number 191736. The seeds were identified by Dr. Regina Celia Viana Martins da Silva, curator of the IAN Embrapa Amazônia Oriental herbarium.

\section{Collection of andiroba oil}

Andiroba oil from $C$. guianensis from each site was processed and characterized separately in the Laboratory for Systematic Investigation in Biotechnology and Fine Chemistry (LabISisBio) at the Federal University of Pará. After collection, the fruits were stored at $12{ }^{\circ} \mathrm{C}$ and transported to the lab where the oil was extracted either with an artisanal extraction process (Shanley et al., 2005) or in natura using organic solvent (Sousa Filho JVC, 2007, MSc dissertation, Universidade Federal do Pará, Belém, PA, Brazil). After artisanal extraction, the resulting mass was pressed and squeezed to reduce the oil content to $<5 \%$, as described elsewhere (Gunstone and Padley, 1997). After extraction in organic solvent, the solvent was removed by evaporation to obtain oil without hexane that could be fractionated and separated. The derivatization technique to characterize the intact oil (sample SW3) and saponified and unsaponified compounds used in this study was essentially that described by Souza et al. (2014), with some modifications in the temperature programming and column change.

\section{Antioxidant assay}

To choose the sample that would be used in this study, the antioxidant capacity of the samples was evaluated by the 2,2-diphenyl-1-picryl-hydrazyl (DPPH) method. The protocol followed was that described by Brand-Williams et al. (1995) with adaptations described by Razali et al. (2008) and Atmani et al. (2009) in which $900 \mu \mathrm{L}$ of DPPH solution $(0.06 \mathrm{mM})$ was mixed with $100 \mu \mathrm{L}$ of oil diluted in methanol $(12.5,25,50,100$ to $200 \mu \mathrm{L} / \mathrm{mL})$ followed by incubation for $20 \mathrm{~min}$. The absorbance was read in a Spectramax M2 spectrophotometer (Molecular Devices, Sunnyvale, CA, USA) at $515 \mathrm{~nm}$. The results were expressed as the percentage inhibition of the DPPH radical that was calculated using the absorbances measured above in conjunction with the following formula:

$$
\% \text { inhibition }=\frac{[A 0-(A 1-A S)]}{A 0} \times 100
$$

where $A 0$ is the absorbance of DPPH, $A 1$ is the absorbance of DPPH + diluted oils and $A s$ is the absorbance of diluted oils. The percentages of inhibition were used to calculate the $\mathrm{EC}_{50}$ (effective concentration or minimum concentration required to reduce the DPPH radical by $50 \%$ ) by non-linear regression. Based on the results of the DPPH assay, the sample with the greatest antioxidant potential (sample SW3) and that was available in sufficient quantity was selected for the in vivo tests.

\section{Experimental design}

For the in vivo assays, 90-day-old non-pregnant nulliparous female Swiss mice (Mus musculus) purchased from the Multidisciplinay Center for Biological Investigation (CEMIB) at the State University of Campinas (UNICAMP), Campinas, SP, Brazil, were used. The mice were maintained in the animal house of the Department of Genetics and Morphology at the University of Brasília under the following conditions: $23 \pm 2{ }^{\circ} \mathrm{C}$, relative humidity $30-70 \%$, and a $12 \mathrm{~h}$ light/dark cycle, with $10-15$ changes of $\mathrm{air} / \mathrm{h}$. The mice had access to drinking water and commercial rodent chow ad libitum. The animal protocols were approved by the Committee for Ethics in Animal Use (CEUA) of the Institute of Biological Sciences at the University of Brasília (protocol no. 127331/2013).

The mice were randomly allocated to one of four experimental groups ( $\mathrm{n}=6$ mice/group): negative control and three doses of oil $(500,1000$ and $2000 \mathrm{mg} / \mathrm{kg} /$ day $)$. The negative control group received corn oil (Salada ${ }^{\circledR}$, Bunge) and the treated mice received a solution of andiroba oil and corn oil by gavage through a gastric tube. The treatments were done for 14 consecutive days and the dose limit corresponded to that recommended in the Organization for Economic Co-operation and Development (OECD) guidelines for the evaluation of genotoxicity by the micronucleus test (Macgregor et al., 1987) and of chromosomal aberrations in bone marrow (Preston et al., 1987). Throughout the experimental period, the mice were weighed on days $0,3,6,9$, 12 and 15 , and food consumption was monitored on days 3 , $6,9,12$ and 15 . All of the mice were examined daily throughout the treatment period to check for possible clinical alterations/symptoms.

On the $15^{\text {th }}$ day the mice were sedated with a mixture of ketamine chlorohydrate (10\%) and xylazine (2\%) and, after confirmation of narcosis, blood samples were obtained. Blood was collected by cardiac puncture and stored in plastic microtubes with 10\% EDTA for hematological evaluation and preparation of slides for the comet assay. During autopsy, the mice were inspected for macroscopic alterations and the liver, kidneys and spleen were collected and weighed. For the micronucleus and nuclear abnormality tests, slides were prepared using femur bone marrow.

\section{Comet assay}

The protocol for this assay was based on the alkaline comet assay $(\mathrm{pH}>13)$ described by Singh et al. (1988), with some modifications. The slides were analyzed in a Zeiss-Axioskop 2 fluorescence microscope fitted with a 510-560 nm filter, a $590 \mathrm{~nm}$ blocking filter and a magnification of 400x. Ethidium bromide $(20 \mu \mathrm{g} / \mathrm{mL})$ was used for staining. Nucleoids were evaluated based on their level of fragmentation that was scored from 0 to 4 (Collins, 2004). For each mouse, 100 cells were evaluated and classified based on the damage caused by the tested substance and 
these data were then used to calculate the damage index (DI). The DI was defined as the product obtained by multiplying the number of comets from each class with the digit denominating the class $(0,1,2,3$ and 4$)$, the formula being taken from Jaloszynski et al. (1997).

\section{Micronucleus test}

The micronucleus test was done using mouse femur bone marrow, as described by Schmid (1975), with modifications. The stained slides were examined with an Olympus $\mathrm{BH} 2$ light microscope at a magnification of 1000x. For each mouse, 4000 erythrocytes were counted, of which 2000 were polychromatic (PCE - polychromatic erythrocytes) and 2000 were normochromatic (NCE - normochromatic erythrocytes). When the cell count reached 2000, the values for the two cell populations were recorded in order to assess the cytotoxicity and calculate the PCE/NCE ratio. The lower this ratio, the greater the cytotoxicity involving a significant reduction in PCE. In addition to this ratio, the appearance of the micronucleated polychromatic cells was also recorded.

\section{Hematological analysis}

For hematological analysis, $370 \mu \mathrm{L}$ of blood containing $10 \%$ disodium EDTA as anticoagulant was analyzed in an automatic veterinary hematocytometer (Sysmex pocH 100iV Diff ${ }^{\mathrm{TM}}$ ) calibrated for mice.

\section{Gas chromatography-mass spectrometry (GC-MS) analysis and compound identification}

GC-MS analysis was done with a Thermo GC/MS system equipped with a quadrupole mass selective detector operated at $70 \mathrm{eV}$ in electron impact (EI) mode. The TRACE-1300 gas chromatograph (GC) was equipped with a RTX-5TG- RESTECK column ( $30 \mathrm{~m}$ x $0.25 \mathrm{~mm}$ di x 0.25 $\mu \mathrm{m}$ film thickness and the oven was operated at $40-300{ }^{\circ} \mathrm{C}$ in increments of $10^{\circ} \mathrm{C} / \mathrm{min}$ with $\mathrm{He}$ as the carrier gas (flow: $1 \mathrm{~mL} / \mathrm{min}$ ). The injector was set at $220^{\circ} \mathrm{C}$ and $1 \mu \mathrm{L}$ of the sample was injected into the GC via an AI/AS-1310 autosampler. The mass spectrometer (MS) was operated in scan mode (start after $3 \mathrm{~min}$, mass range from 40-800 a.m.u. at 1 $\mathrm{scan} / \mathrm{s})$. The transfer line and ion source were both operated at $280{ }^{\circ} \mathrm{C}$. The compounds were identified by comparing their mass spectra with those of the NIST-11MS lipid library database.

\section{Statistical analysis}

The $\mathrm{EC}_{50}$ (effective concentration capable of inhibiting $50 \%$ of the free radical) was calculated by non-linear regression from the percentage inhibition of the free radical in the DPPH assay for the 21 samples of andiroba oil. The quantitative data were evaluated by parametric or nonparametric statistical methods based on the normal distribution of the data. Parametric data were compared by analysis of variance (ANOVA) followed by Dunnett's test, whereas non-parametric data were analyzed with the Wilcoxon text followed by the Kruskall-Wallis test. All data comparisons and statistical analyses were done using the softwares Instat 3.02 and Prism 5.0 (GraphPad Inc., La Jolla, CA, USA), with a value of $p \leq 0.05$ indicating significance.

\section{Results}

All of the oil samples showed antioxidant activity towards the DPPH radical, as shown in Table 1, which summarizes the $\mathrm{EC}_{50}$ data. Supplementary Figures S1-S7 show that there was a correlation between the percentage of DPPH inhibition and the oil concentration needed to cause a 50\% reduction of DPPH. Samples with high and low antioxidant properties showed regional variations, e.g., northeastern Pará State, Marajó island and the metropolitan region of Belém, as well as variations within each region. Two commercial samples of andiroba oil (Amazon Ervas and Iana ${ }^{\circledR}$ D'amazônia) were also tested for their antioxidant potential. The Iana sample, diluted in mineral oil as stated on the manufacturer's label, had the lowest antioxidant capacity of all the samples tested, with an $\mathrm{EC}_{50}$ of 8913 $\mu \mathrm{L} / \mathrm{mL}$, compared to $204.8 \mu \mathrm{L} / \mathrm{mL}$ for the Amazon Ervas sample, which was similar to the value for the Cametá sample from northeastern Brazil.

Based on these results and the availability of each oil, the sample SW3 was chosen for biological assays. The lipid profiles were determined using the derivatization technique. Saponified compounds represented $>97 \%$ of the sample and non-saponified compounds consisted of steroids and triterpenoids derivatives (Table 2). More than $97 \%$ of the fatty acids were represented by oleic, palmitic, stearic, linoleic and arachidonic acids. However, the derivatization technique was also capable of detecting traces of other acids in the same sample. These findings agreed with those reported for other analyses of andiroba oil (Martinborough, 2002).

To evaluate the possible toxicity of SW3 in vivo, the mice were observed daily for any alterations during treatment, but no clinical or behavioral alterations were observed and there were no changes in body weight. No macroscopic alterations were seen during autopsy nor were there any alterations in the absolute or relative weight of the kidneys, liver or spleen (Table 3).

The comet assay (Figure 1) and micronucleus test (Table 4) were used to assess the genotoxicity of SW3. No significant alterations were observed in micronucleus formation or DNA fragmentation during treatment with andiroba oil. There were also no hematological alterations in the mice or nuclear abnormalities in blood cells (polymorphonuclear or normonuclear cells) (Table 5). 
Table 2 - Profile of fatty acids, steroids and triterpenes present in two samples (SW3-1 and SW3-2) of andiroba oil.

\begin{tabular}{|c|c|c|c|c|c|}
\hline \multirow[t]{2}{*}{ Component } & \multirow[t]{2}{*}{ Peak retention time (min) } & \multirow{2}{*}{$\begin{array}{c}\text { Retention index } \\
\text { Lipids } 1(\%)\end{array}$} & \multirow{2}{*}{$\begin{array}{c}\text { Oil profile } \\
\text { Lipids } 2(\%)\end{array}$} & \multirow[t]{2}{*}{ SW3-1 } & \multirow[t]{2}{*}{ SW3-2 } \\
\hline & & & & & \\
\hline \multirow[t]{9}{*}{ Fatty acids } & 15.52 & 1899 & Miristic acid & $0.07 \pm 0.03$ & $0.13 \pm 0.02$ \\
\hline & 17.54 & 2027 & Palmitic acid & $37.95 \pm 0.63$ & $32.21 \pm 0.94$ \\
\hline & 17.86 & 2048 & Palmitoleic acid & $0.07 \pm 0.12$ & $0.81 \pm 0.07$ \\
\hline & 20.49 & 2234 & Oleic acid & $55.23 \pm 0.43$ & $41.92 \pm 0.52$ \\
\hline & 21.37 & 2301 & Linoleic acid & $4.21 \pm 0.34$ & $7.63 \pm 0.36$ \\
\hline & 21.58 & 2318 & Stearic acid & $0.03 \pm 0.06$ & $14.53 \pm 0.75$ \\
\hline & 22.93 & 2428 & Arachidic acid & $1.07 \pm 0.19$ & $2.12 \pm 0.39$ \\
\hline & 25.52 & 2664 & Behenic acid & $0.28 \pm 0.07$ & $0.43 \pm 0.06$ \\
\hline & 27.73 & 2894 & Lignoceric acid & $0.17 \pm 0.06$ & $0.25 \pm 0.01$ \\
\hline \multirow[t]{3}{*}{ Steroids } & 28.59 & Ns & Squalene & $0.43 \pm 0.61$ & - \\
\hline & 30.86 & Ns & Stigmasterol & $0.11 \pm 0.04$ & - \\
\hline & 31.87 & Ns & Cholesterol & $0.07 \pm 0.02$ & - \\
\hline \multirow[t]{5}{*}{ Triterpenes } & 33.11 & Ns & Epoxygedunnin* & $0.08 \pm 0.02$ & - \\
\hline & 33.64 & Ns & 1,3-Dipalmitin & $0.09 \pm 0.02$ & - \\
\hline & 33.94 & Ns & $\begin{array}{l}\text { Deoxylactone-derivativ } \\
\mathrm{e}\end{array}$ & $0.13 \pm 0.02$ & - \\
\hline & 35.92 & Ns & Deacetylgedunin* & $0.04 \pm 0.01$ & - \\
\hline & 36.40 & Ns & Epoxydeacetylgedunin* & $0.06 \pm 0.03$ & - \\
\hline
\end{tabular}

$\mathrm{Ns}=$ not simulated (requires hydrocarbons with a carbon number $>30$ ), *Tentative identification. Lipids $1=$ fermented seeds (extracted by oil dripping). Lipids $2=$ non-fermented seeds (extracted with solvent). The values are the mean \pm SD of chromatographic quantifications. Retention Index: relative retention-time of a compound within the chromatograph according to its chromatographic properties. SW3-1 and SW3-2 means two chromatographic analysis of same sample.

Table 3 - Absolute and relative weights of mouse organs after treatment with andiroba oil.

\begin{tabular}{|c|c|c|c|c|}
\hline & \multirow[b]{2}{*}{ Negative control } & \multicolumn{3}{|c|}{ Andiroba oil (mg/kg/day) } \\
\hline & & 500 & 1000 & 2000 \\
\hline \multicolumn{5}{|c|}{ Absolute weight } \\
\hline Liver & $1.82 \pm 0.29$ & $1.96 \pm 0.31$ & $1.86 \pm 0.17$ & $2.16 \pm 0.30$ \\
\hline Spleen & $0.15 \pm 0.08$ & $0.15 \pm 0.02$ & $0.13 \pm 0.01$ & $0.13 \pm 0.02$ \\
\hline Right kidney & $0.17 \pm 0.02$ & $0.18 \pm 0.02$ & $0.17 \pm 0.02$ & $0.20 \pm 0.02$ \\
\hline Left kidney & $0.18 \pm 0.02$ & $0.18 \pm 0.02$ & $0.17 \pm 0.01$ & $0.19 \pm 0.02$ \\
\hline \multicolumn{5}{|c|}{ Relative weight } \\
\hline Liver & $4.81 \pm 0.19$ & $5.10 \pm 0.35$ & $5.26 \pm 0.51$ & $5.29 \pm 0.45$ \\
\hline Spleen & $0.39 \pm 0.16$ & $0.40 \pm 0.08$ & $0.39 \pm 0.08$ & $0.33 \pm 0.05$ \\
\hline Right kidney & $0.46 \pm 0.05$ & $0.48 \pm 0.03$ & $0.48 \pm 0.05$ & $0.49 \pm 0.05$ \\
\hline Left kidney & $0.47 \pm 0.05$ & $0.47 \pm 0.04$ & $0.48 \pm 0.05$ & $0.48 \pm 0.06$ \\
\hline
\end{tabular}

The relative weight is expressed in relation to the final body weight of each animal. The values are the mean $\pm \mathrm{SD}(\mathrm{n}=6$ animals/group) and were analyzed by ANOVA or the Kruskal-Wallis test, depending on the normality of the data distribution. There were no significant differences between the responses to andiroba oil and the negative control, or among the doses of oil tested. 


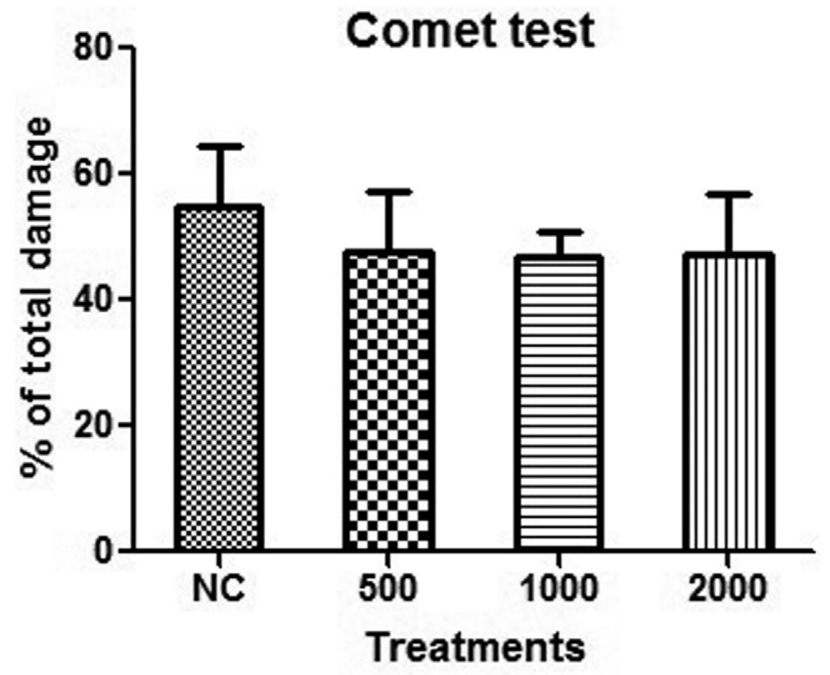

Figure 1 - Comet test. The doses of andiroba oil are in $\mathrm{mg} / \mathrm{kg} / \mathrm{day}$. $\mathrm{NC}-$ negative control. The columns represent the mean \pm SD and were analyzed by ANOVA. There were no significant differences between the responses to andiroba oil and the negative control, or among the doses of oil tested.

\section{Discussion}

Toxicological and genotoxicity studies are required to assess the efficiency and safety of natural products used to treat diseases among Amazonian and other populations, whereas chemical analyses are important in determining the lipid profiles of these products. Assessment of potential genotoxicity is particularly important since such toxicity is considered to be fundamental in the development of diseases such as cancer (Ribeiro et al., 2003). Lipids play an important role in the toxicity of natural oils, and investigation of the lipid composition of andiroba oil can provide insight into their contribution to the biological activity of this oil. In addition, the lipid profile of the original (natural) oil extracted from seeds and the profile of oil produced after fermentation of the seeds must be compared to determine whether there are significant differences between them.

Stearic, palmitic, oleic and linoleic acids can cause cellular apoptosis (Mu et al., 2001; Lu et al., 2003; CuryBoaventura et al., 2004), but nothing has been published about linked free fatty acids (FFA). Although there are ma- jor differences between FFA and esterified fatty acids, FFA are not neutral molecules and their biological activities are not the same as those of linked FFA. In this context, lipidomics provides a useful strategy for analyzing total and fractionated oils, with acidity being related to the FFA released during oil processing and extraction.

Since one of the pathways leading to apoptosis involves DNA degradation (Grivicich et al., 2007) it is worth considering whether the concentrations of lipid components in andiroba oil are sufficient to trigger apoptosis by damaging genetic material. In this case, only FFA can cause damage and analysis of the unfractionated natural oil is required to provide a reference for comparison; the latter should be investigated first, followed by an analysis of oil fractions.

In this study, we used the comet and micronucleus tests, two validated genotoxicity bioassays, to screen andiroba oil for toxicity. These tests can identify damage to DNA and indicate its extent and gravity (Wong et al., 2005; Asare et al., 2011). The comet assay quantifies lesions to DNA in individual cells (Tice et al., 2000; Collins, 2004), whereas the micronucleus test indicates chromosomal instability (Jagetia and Reddy, 2002). The PCE/NCE (polychromatic erythrocyte/normochromatic erythrocyte) ratio is another parameter that can be assessed during micronuclear analysis. The progression of erythroblasts from the PCE stage to NCE stage is an indicator of the acceleration or inhibition of erythropoiesis, with a decrease in the ratio indicating cytotoxicity (Venkatesh et al., 2007).

As shown here, treatment of mice with andiroba oil did not damage the DNA of blood cells (comet assay), nor was there a significant increase in MN-PCE frequency or a decrease in the PCE/NCE ratio for any of the oil samples tested (micronucleus test). The latter finding indicated that there was no chromosomal structural and/or numerical damage in the erythroblasts of Swiss mice treated with andiroba oil and there was no cytotoxicity to bone marrow. Together, these findings indicate that andiroba oil is not genotoxic, cytotoxic or mutagenic. Similar results have been reported for other plant oils, such as oil from pequi (Caryocar brasiliense) (Roll MM, 2013, MSc dissertation, Universidade de Brasília, Brasília, DF, Brazil) and oil extracted from the fruit of Litsea cubeba (Luo et al., 2005).

Table 4 - Frequency of micronuclei after treatment with andiroba oil.

\begin{tabular}{lcccc}
\hline & & \multicolumn{3}{c}{ Andiroba oil (mg/kg/day) } \\
\cline { 3 - 5 } Parameter & Negative control & 500 & 1000 & 2000 \\
\hline MN-PCE (number) & $1.66 \pm 2.42$ & $2 \pm 2.09$ & $1.16 \pm 1.60$ & $2.5 \pm 1.22$ \\
MN-PCE (\%) & $8.33 \pm 12.11$ & $10.00 \pm 10.49$ & $5.83 \pm 8.01$ & $12.50 \pm 6.12$ \\
PCE/NCE ratio & $1.77 \pm 0.57$ & $2.39 \pm 0.60$ & $2.10 \pm 0.63$ & $2.29 \pm 0.42$ \\
\hline
\end{tabular}

$\mathrm{MN}$ - micronuclei, $\mathrm{NCE}$ - normochromatic erythrocytes, $\mathrm{PCE}$ - polychromatic erythrocytes. The values represent the mean $\pm \mathrm{SD}$ and were analyzed by ANOVA. There were no significant differences between the responses to andiroba oil and the negative control, or among the doses of oil tested. 
Table 5 - Erythrocyte, leukocyte and platelet counts and characteristics after treatment with andiroba oil.

\begin{tabular}{|c|c|c|c|c|}
\hline \multirow[b]{2}{*}{ Parameters } & \multirow[b]{2}{*}{ Negative control } & \multicolumn{3}{|c|}{ Andiroba oil (mg/kg/day) } \\
\hline & & 500 & 1000 & 2000 \\
\hline \multicolumn{5}{|l|}{ Erythrocytes } \\
\hline $\mathrm{RBC} \times 10^{6} / \mu \mathrm{L}$ & $8.80 \pm 0.35$ & $8.93 \pm 0.40$ & $9.04 \pm 0.29$ & $8.57 \pm 0.38$ \\
\hline $\operatorname{HGB}(\mathrm{g} / \mathrm{dL})$ & $12.48 \pm 0.45$ & $12.50 \pm 0.41$ & $12.65 \pm 0.40$ & $12.07 \pm 0.42$ \\
\hline HCT (\%) & $32.23 \pm 1.22$ & $32.58 \pm 1.12$ & $32.75 \pm 0.91$ & $31.38 \pm 1.05$ \\
\hline MCV (fL) & $36.7 \pm 0.69$ & $36.5 \pm 0.72$ & $36.2 \pm 0.53$ & $36.6 \pm 0.64$ \\
\hline $\mathrm{MCH}(\mathrm{pg})$ & $14.2 \pm 0.3$ & $14.0 \pm 0.5$ & $14.0 \pm 0.2$ & $14.1 \pm 0.2$ \\
\hline $\mathrm{MCHC}(\mathrm{g} / \mathrm{dL})$ & $38.7 \pm 0.41$ & $38.4 \pm 0.56$ & $38.6 \pm 0.48$ & $38.5 \pm 0.31$ \\
\hline RDW (\%) & $13.57 \pm 0.69$ & $14.37 \pm 1.13$ & $14.17 \pm 0.83$ & $13.62 \pm 0.78$ \\
\hline \multicolumn{5}{|l|}{ Leukocytes } \\
\hline $\mathrm{WBC} \times 10^{3} / \mu \mathrm{L}$ & $2.23 \pm 1.12$ & $2.32 \pm 1.16$ & $2.53 \pm 1.13$ & $1.78 \pm 0.75$ \\
\hline W-SCR $(\%)$ & $71.57 \pm 9.24$ & $71.45 \pm 16.52$ & $75.95 \pm 10.58$ & $76.38 \pm 9.21$ \\
\hline W-MCR (\%) & $27.78 \pm 8.41$ & $28.00 \pm 16.16$ & $23.57 \pm 10.27$ & $22.38 \pm 7.28$ \\
\hline W-LCR (\%) & $0.65 \pm 1.02$ & $0.38 \pm 0.52$ & $0.48 \pm 0.68$ & $1.23 \pm 2.88$ \\
\hline \multicolumn{5}{|l|}{ Platelets } \\
\hline PLT $\times 10^{3} / \mathrm{mL}$ & $1371 \pm 207$ & $1479 \pm 248$ & $1442 \pm 231$ & $1340 \pm 295$ \\
\hline PDW (fL) & $7.02 \pm 0.48$ & $7.00 \pm 0.20$ & $6.80 \pm 0.11$ & $7.00 \pm 0.17$ \\
\hline MPV (fL) & $6.53 \pm 0.48$ & $6.48 \pm 0.31$ & $6.42 \pm 0.13$ & $6.38 \pm 0.19$ \\
\hline P-LCR (\%) & $7.28 \pm 3.27$ & $7.04 \pm 2.04$ & $7.28 \pm 1.05$ & $6.10 \pm 1.75$ \\
\hline
\end{tabular}

$\mathrm{HCT}$ - hematocrit, $\mathrm{HGB}$ - hemoglobin, $\mathrm{MCH}$ - mean corpuscular hemoglobin, $\mathrm{MCHC}$ - mean corpuscular hemoglobin concentration, $\mathrm{MCV}$ - mean corpuscular volume, MPV - mean platelet volume, PDW - platelet distribution width, PLT - platelets, P-LCR - platelet large cell ratio, RBC - red blood cells (erythrocytes), RDW - red cell distribution width, WBC - white blood cells (leukocytes), W-LCR - eosinophils, W-MCR - neutrophils + monocytes, W-SCR - lymphocytes, $\mathrm{fL}$ - femtoliter, $\mathrm{g} / \mathrm{dL}-\mathrm{g}$ /deciliter, $\mathrm{pg}$ - picogram. The values represent the mean $\pm \mathrm{SD}$ and were analyzed by ANOVA. There were no significant differences between the responses to andiroba oil and the negative control, or among the doses of oil tested.

Since no genotoxicity was observed in this study, the apoptosis caused by fatty acids (stearic, palmitic, oleic and linoleic acids) may not originate from genetic damage, in a manner similar to that reported for limonoids, substances also found in andiroba oil that cause cell apoptosis via the mitochondrial route (Kikuchi et al., 2011). Another possible explanation could be that the concentration of these fatty acids in andiroba oil is insufficient to trigger this type of cell death; this would mean that andiroba oil could be classified as a GRAS (Generally Recognized as Safe) product that is good enough to use in ointments.

The doses used in this study can be compared with those used by Costa-Silva et al. (2008) in acute tests with Wistar rats. These authors used a dose of andiroba oil (5 $\mathrm{g} / \mathrm{kg}$ ) that was much higher than that used here and also found no adverse effects in histological, biochemical and hematological analyses; they estimated the lethal dose $\left(\mathrm{LD}_{50}\right)$ to be $>5 \mathrm{~g} / \mathrm{kg}$. Since mice, which have a low body mass, were used in the present study, we opted to follow the doses described in the OECD (1997) Guidelines 474 (mammalian erythrocyte micronucleus test) and 475 (mammalian bone marrow chromosome aberration test), these doses being 500,1000 and $2000 \mathrm{mg} / \mathrm{kg} /$ day for 14 days.
There were no significant changes in body weight or in the absolute and relative weights for liver, spleen and the left and right kidneys after treatment. Costa-Silva et al. (2008) also noted that there were no significant alterations in Wistar rats treated for 14 days with andiroba oil at doses much higher than those administered here. Increases in plasma alanine aminotransferase (ALT) and in the relative and absolute liver weights are generally indicative of hepatic toxicity. The absence of such changes in the present study indicated that andiroba oil was not toxic to mice. There were also no significant changes in any of the blood parameters. Overall, these findings indicate that there were no significant alterations in any of the hematological, biochemical and morphological parameters investigated.

Since the doses of andiroba oil used in this study were similar to those used in phytotherapy, we conclude that the risk of toxicity from this oil when used in humans is very low. In addition, the DPPH test clearly demonstrated the antioxidant activity of all 21 samples of andiroba oil, although there was considerable variation among them. This antioxidant activity could protect DNA from oxidative damage. In an analysis of the chemical composition analysis of andiroba oil, Martinborough (2002) detected terpenes in the non-saponifiable portion of the oil; terpenes are be- 
lieved to contribute to the antioxidant activity of the oil. However, Wu et al. (2013) indicated that the antioxidant activity of an essential oil can be attributed to components present in great quantity, although synergistic or antagonistic mechanisms may also be involved.

Based on the information available at the moment, it is not yet possible to attribute antioxidant activities to a specific compound in andiroba oil. Such identification would initially require separation of the oil components followed by individual analysis of the DPPH-reducing activity by thin layer chromatography (TLC) to compare the antioxidant activity of different classes of substances. The DPPH test was found to be useful for detecting regional as well as geographic variation in the antioxidant capacity of andiroba oil samples in the state of Pará.

Variations in antioxidant activity may be associated with climatic or environmental differences, or may reflect genetic variability and the diversity of collected specimens. In the state of Pará, the rains last from December to July, with peak rainfall from March to May (Moraes et al., 2005). Among the samples analyzed, most collections occurred between March and July, thus covering much of the wet season. Consequently, the variation in antioxidant capacity probably did not reflect climatic differences. Tian et al. (2014) suggested that variation in the chemical composition and antioxidant capacity of the herb Perilla frutescens from which essential oil is extracted in China may be the result of genetic and/or environmental factors. Similar factors could account for the differences in the antioxidant capacity of andiroba oil. The DPPH test was particularly useful for screening andiroba oil that was sold diluted in mineral oil, as in the case of the Iana sample. Dilution in mineral oil reduces the oil's antioxidant capacity and attenuates the therapeutic properties such as acaricidal activity (Farias et al., 2007, 2009), larvicidal action (Silva et al., 2004) and insect repellent action (Miot et al., 2004, 2011).

Comparison of the $\mathrm{EC}_{50}$ of the most active sample of andiroba oil, LAM $1\left(\mathrm{EC}_{50}=43.56\right)$, and the sample used in most of the experiments described here, namely, SW3 $\left(\mathrm{EC}_{50}=59.95\right)$, with samples from other studies, such as pequi oil $\left(\mathrm{EC}_{50}=26.26\right)($ Roll MM, 2013, MSc dissertation, Universidade de Brasília, Brasília, DF, Brazil) indicated that higher values were obtained with andiroba oil, i.e., this oil had a lower antioxidant potential than pequi oil.

Overall, our data extend our knowledge of the risks of adverse toxic effects and the potential phytotherapeutic uses of andiroba oil. In the experimental conditions used here, andiroba oil was not hematotoxic, genotoxic, mutagenic or cytotoxic. On the contrary, the antioxidant activity of the oil would tend to protect cellular DNA from oxidative damage. In conclusion, andiroba oil, which is used in folk medicine among Amazonian populations, has a low risk of toxicity under the conditions in which it was tested here.

\section{Acknowledgments}

This work was supported by a post-doctoral fellowship from the National Council for Scientific and Technological Development (CNPq). Additional support for this project was provided by the National Council for the Improvement of Higher Education (CAPES) from the Pró-Amazonia Project (grant no. 3284/2013).

\section{References}

Asare GA, Gyan B, Bugyei K, Adjei S, Mahama R, Addo P, Out-Nyarko L, Wiredu EK and Nyarko A (2011) Toxicity potentials of the nutraceutical Moringa oleifera at suprasupplementation levels. J Ethnopharmacol 139:265-272.

Atmani D, Chaher N, Berboucha M, Ayouni K, Lounis H, Boudaoud H, Debbache N and Atmani D (2009) Antioxidant capacity and phenol content of selected Algerian medicinal plants. Food Chem 112:303-309.

Bauch J and Dunisch O (2000) Comparison of growth dynamics and wood characteristics of plantation grown and primary forest Carapa guianensis in central Amazonia. IAWA J 21:321-333.

Brand-Williams W, Cuvelier ME and Berset CLWT (1995) Use of a free radical method to evaluate antioxidant activity. LWT-Food Sci Technol 28:25-30.

Collins AR (2004) The comet assay for DNA damage and repair: Principles, applications, and limitations. Mol Biotechnol 26:249-261.

Costa-Silva JH, Lima CR, Silva EJR, Araújo AV, Fraga MCCA, Ribeiro E, Ribeiro A, Arruda AC, Lafayette SSL and Wanderley AG (2008) Acute and subacute toxicity of the Carapa guianensis Aublet (Meliaceae) seed oil. J Ethnopharmacol 116:495-500.

Curi R, Miyasaka CK, Pompéia C and Procopio J (2002) Entendendo a Gordura - Os Ácidos Graxos. Editora Manole, Barueri, $583 \mathrm{p}$.

Cury-Boaventura MF, Pompéia C and Curi R (2004) Comparative toxicity of oleic acid and linoleic acid on Jurkat cells. Clin Nutr 23:721-732.

Farias MPO, Sousa DP, Arruda AC, Arruda MSP, Wanderley AG, Alves LC and Faustino MAG (2007) Eficácia in vitro do óleo da Carapa guianensis Aubl. (andiroba) no controle de Boophilus microplus (Acari, Ixodidae). Rev Bras Plantas Medicinais 9:68-71.

Farias MPO, Sousa DP, Arruda AC, Wanderley AG, Teixeira WC, Alves LC and Faustino MAG (2009) Potencial acaricida do óleo de andiroba Carapa guianensis Aubl. sobre fêmeas adultas ingurgitadas de Anocentor nitens Neumann, 1897 e Rhipicephalus sanguineus Latreille, 1806. Arq Bras Med Vet Zootec 61:877-882.

Ferraz IDK, Camargo JLC and Sampaio PTB (2002) Sementes e plântulas de andiroba (Carapa guianensis AUBL. e Carapa procera D.C.): Aspectos botânicos, ecológicos e tecnológicos. Acta Amaz 32:647-661.

Ferreira MR, Santiago RR, de Souza TP, Egito ES, Oliveira EE and Soares LA (2010) Development and evaluation of emulsions from Carapa guianensis (andiroba) oil. AAPS Pharm Sci Technol 11:1383-1390.

Fisch STV, Ferraz IDK and Rodrigues WA (1995) Distinguishing Carapa guianensis Aubl. from Carapa procera D.C. (Meliaceae) by morphology of young seedlings. Acta Amaz 25:193-200. 
Grivicich I, Regner A and Rocha AB (2007) Apoptosis: Programmed cell death. Rev Bras Cancerol 53:335-343.

Gunstone FD and Padley FB (1997) Lipid Technologies and Applications. Marcel Dekker, New York, 837 pp.

Jagetia GC and Reddy TK (2002) The grapefruit flavanone naringin protects against the radiation-induced genomic instability in the mice bone marrow: A micronucleus study. Mutat Res 519:37-48

Jaloszynski P, Kujawski M, Czub-Swierczek M, Markowska J and Szyfter K (1997) Bleomycin-induced DNA damage and its removal in lymphocytes of breast cancer patients studied by comet assay. Mutat Res 385:223-233.

Kikuchi T, Ishii K, Noto T, Takahashi A, Tabata K, Suzuki T and Akihisa T (2011) Cytotoxic and apoptosis-inducing activities of limonoids from the seeds of Azadirachta indica (Neem). J Nat Prod 74:866-870.

Lu Z, Mu Y, Wang B, Li X, Lu J, Li J, Pan C, Yanase T and Nawata H (2003) Saturated free fatty acids, palmitic acid and stearic acid, induce apoptosis by stimulation of ceramide generation in rat testicular Leydig cell. Biochem Biophys Res Commun 303:1002-1007.

Luo M, Jiang LK and Zou GL (2005) Acute and genetic toxicity of essential oil extracted from Litsea cubeba (Lour.) Pers. J Food Prot 68:581-588.

Macgregor JT, Heddle JA, Hite M, Margolin BH, Ramel C, Salamone MF, Tice RR and Wild D (1987) Guidelines for the conduct of micronucleus assays in mammalian bone marrow erythrocytes. Mutat Res 189:103-112.

Martinborough T (2002) Karaba Oil (Crabwood Oil): A Literature Review. The Iwokrama International Centre for Rain Forest, Conservation and Development, Georgetown, $7 \mathrm{pp}$.

Miot HA, Batistella RF, Batista KA, Volpato DEC, Augusto LST, Madeira NG, Haddad-Junior V and Miot LDB (2004) Comparative study of the topical effectiveness of the andiroba oil (Carapa guianensis) and DEET 50\% as repellent for Aedes sp. Rev Inst Med Trop São Paulo 46:253-256.

Miot HA, Lauterbach GP, Ribeiro FAH, Favero Júnior EL, Hercos GN, Madeira NG and Haddad-Junior V (2011) Comparison among homemade repellents made with cloves, picaridin, Andiroba, and soybean oil against Aedes aegypti bites. Rev Soc Bras Med Trop 44:793-794.

Moraes BC, Costa JMN, Costa ACL and Costa MH (2005) Variação espacial e temporal da precipitação no estado do Pará. Acta Amaz 35:207-214.

Mu Y, Yanase T, Nishi Y, Tanaka A, Saito M, Jin C, Mukasa C, Okabe T, Nomura M, Goto K, et al. (2001) Saturated FFAs, palmitic acid and stearic acid induce apoptosis in human granulosa cells. Endocrinology 142:3590-3597.

OECD (1997) Guideline for the Testing of Chemicals, Mammalian Erythrocyte Micronucleus Test, number 474. Section 4. OECD Publishing, Paris.

Preston RJ, Dean BJ, Galloway S, Holden H, Mcfee AF and Shelby M (1987) Mammalian in vivo cytogenetic assays. Analysis of chromosome aberrations in bone marrow cells. Mutat Res 189:157-165.

Razali N, Razab R, Junit SM and Aziz AA (2008) Radical scavenging and reducing properties of extracts of cashew shoots (Anacardium occidentale). Food Chem 111:38-44.

Ribeiro LR, Salvadori DMF and Marques EK (2003) Mutagênese Ambiental. Editora da ULBRA, Canoas, 355 pp.

Schmid W (1975) The micronucleus test. Mutat Res 31:9-15.
Shanley P, Serra M and Medina G (2005) Frutíferas e Plantas Úteis na Vida Amazônica. Editora Supercores, Belém, 316 p.

Silva OS, Romão PR, Blazius RD and Prohiro JS (2004) The use of Andiroba Carapa guianensis as larvicide against Aedes albopictus. J Am Mosq Control Assoc 20:456-457.

Singh NP, Mccoy MT, Tice RR and Schneider EL (1988) A simple technique for quantitation of low levels of DNA damage in individual cells. Exp Cell Res 175:184-191.

Souza JMM, Berkov S and Santos AS (2014) Improvement of friable callus production of Boerhaavia paniculata Rich and the investigation of its lipid profile by GC/MS. An Acad Bras Cienc 86:1015-1027.

Tian J, Zeng X, Zhang S, Wanga Y, Zhang P, Lü A and Peng X (2014) Regional variation in components and antioxidant and antifungal activities of Perilla frutescens essential oils in China. Ind Crop Prod 59:69-79.

Tice RR, Agurell E, Anderson D, Burlinson B, Hartmann A, Kobayashi H, Miyamae Y, Rojas E, Ryu JC and Sasaki YF (2000) Single cell gel/comet assay: Guidelines for in vitro and in vivo genetic toxicology testing. Environ Mol Mutagen 35:206-221.

Venkatesh P, Shantala B, Jagetia GC, Rao KK and Baliga MS (2007) Modulation of doxorubicin-induced genotoxicity by Aegle marmelos in mouse bone marrow: A micronucleus study. Integr Cancer Ther 6:42-53.

Wong VWC, Szeto YT, Collins AR and Benzie IFF (2005) The comet assay: A biomonitoring tool for nutraceutical research. Curr Top Nutraceut Res 3:1-14.

Wu Z, Li H, Yang Y, Zhan Y and Tu DW (2013) Variation in the components and antioxidant activity of Citrus medica L. var. sarcodactylis essential oils at different stages of maturity. Ind Crop Prod 46:311-316.

\section{Internet Section}

Rain-Tree (2014). Tropical Plant Database, http://www.rain-tree.com/Andiroba.htm (accessed on 26/06/2014).

\section{Supplementary material}

Figure S1 - Percentage inhibition of DPPH by Southeast (SE) samples $1-3$. The points represent the mean $\pm \mathrm{SD}$ of SE.

Figure S2 - Percentage inhibition of DPPH by Northeast (NE) samples $1-3$. The points represent the mean $\pm \mathrm{SD}$ of $\mathrm{NE}$.

Figure S3 - Percentage inhibition of DPPH by Lower Amazon (LAM) samples 1-3. The points represent the mean \pm SD of LAM.

Figure S4 - Percentage inhibition of DPPH by Marajó (MAR) samples 1-3. The points represent the mean \pm SD of MAR.

Figure S5 - Percentage inhibition of DPPH by Metropolitan (MTR) samples 1-3. The points represent the mean \pm SD of MTR.

Figure S6 - Percentage inhibition of DPPH by Southwest (SW) samples 1-6. The points represent the mean \pm SD of SW.

Figure S7 - Percentage inhibition of DPPH by commercial samples of andiroba oil. The points represent the mean \pm SD of commercial samples.

Associate Editor: Daisy Maria Fávero Salvadori

License information: This is an open-access article distributed under the terms of the Creative Commons Attribution License (type CC-BY), which permits unrestricted use, distribution and reproduction in any medium, provided the original article is properly cited. 